\title{
A emergência da reação estética da criança na atividade musical ${ }^{\star}$
}

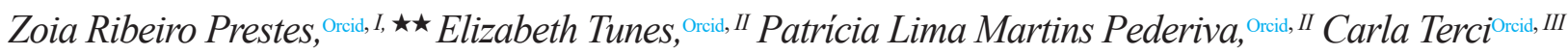 \\ ${ }^{I}$ Universidade Federal Fluminense, Niterói, RJ, Brasil \\ ${ }^{I I}$ Universidade de Brasília, Brasília, DF, Brasil

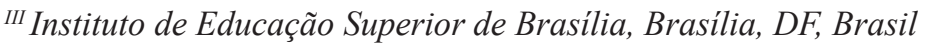

\begin{abstract}
Resumo
Com base na psicologia histórico-cultural, o presente projeto teve por objetivo estudar a emergência da reação estética na criança. Para tanto, foram realizadas sessões de audição musical dialogada com crianças na faixa etária dos sete aos doze anos de idade. Elas ouviam alguns trechos de composições musicais previamente escolhidos pelos pesquisadores e, em seguida, seu diálogo com eles foi gravado por meio de vídeos. Foram observadas suas reações (gestos, expressões e comentários), no decorrer da audição e, após, indagou-se se sentiram ou não alguma emoção e, em caso positivo, se conseguiam identificar quais foram as reações emocionais sentidas. Os dados obtidos foram analisados com vistas à descrição de suas reações e com base nos estudos da teoria histórico-cultural. Verificou-se, ao longo da análise dos resultados, que as sessões de audição musical dialogada mostram-se uma atividade adequada para o estudo da emergência da reação estético-musical na criança a partir de sete anos de idade.
\end{abstract}

Palavras-chave: reação estética; desenvolvimento; criança.

\section{The emergence of musical aesthetic reaction in children}

\begin{abstract}
Based on cultural-historical psychology, this project aimed to study the emergence of aesthetic response in children. Thus, we carried out music listening sessions with children aged seven to twelve. They heard snippets of musical compositions previously chosen by the researchers, and then, their dialogue with them was recorded on camera. Their reactions were observed (gestures, expressions and comments) in the course of the session. After that, they were asked whether or not they felt some emotion and, if so, whether they could identify which were the emotional reactions experienced. The data were analyzed in order to describe their reactions, based on the cultural-historical psychology. Analysing these results, it was found that music listening sessions carried out along with conversation are suitable for the study of the emergency of aesthetic response in children aged seven or more.
\end{abstract}

Keywords: aesthetic reaction; development; child.

\section{Introdução}

A música ocupa lugar de grande importância e significado na vida humana, desde as mais remotas épocas da história e da cultura. A busca de uma compreensão de seu papel na vida e de seu significado psicológico requer entendê-la no seu caráter geral, bem como examinar as razões que a situam como arte.

O som musical é, antes de tudo, elaborado pela arte e pela expressão artística. Ele não está lá, disponível, exterior, como o material das outras artes, para que tome forma. Por sua natureza, ele já é interior e assim continuará mesmo enformado por meio da arte. É desse modo que nasce e é por essa via de interioridade que se transforma, mantendo essa característica. A música, som elaborado, surge em meio ao próprio trabalho ou atividade artística de sua organização e sistematização. Para existir como arte, o som requer elaboração. Sem isso, ele é apenas natural e espontâneo. Mas, mesmo transformado pela arte, não perde sua natureza interior. Por isso, a expressão musical possui o sentido interior da coisa e o sentimento que também é algo interior como conteúdo. Por essa interioridade, na música, cada indivíduo é reivindicado como pessoa singular, levado para dentro de si mesmo pela natureza interior e interiorizadora do som, captado

\footnotetext{
${ }^{\star} \mathrm{O}$ presente trabalho é parte de pesquisa financiada pelo CNPq, processo $\mathrm{n}^{0}$ 400780/2010-0 (edital 2010/0).

$\star \star$ Endereço para correspondência: Universidade Federal Fluminense, Faculdade de Educação. Rua Prof. Marcos Waldemar de Freitas Reis, s/n, Bloco D, Campus do Gragoatá, Centro, Niterói, RJ - Brasil. CEP: 24210-201. E-mail: zoiaprestes@yahoo.com.br, bethtunes@gmail.com, pat.pederiva@gmail.com, carlaterci@gmail.com
}

segundo particularidades, apreendido por determinados conteúdos e, além disso, é levado para dentro da obra, de acordo com o simples si mesmo, o interior, segundo o cerne de sua existência espiritual (HEGEL, 2002).

Assim, o fio condutor da música, da atividade musical e da musicalidade será sempre a interioridade porque ela é própria da natureza do som. Nesse processo, cria-se a condição de possibilidade de que cada indivíduo, na vivência da reação estética, seja reivindicado como pessoa singular. Para Hegel (2002), não se pode entender como arte musical o som expresso como interjeição, grito de dor, suspiro ou riso. Expresso dessa forma, de modo natural, o som já é a exteriorização imediata e viva dos sentimentos e dos estados de alma. Não se poderia denominar de música, segundo o autor, a expressão meramente natural das interjeições, pois elas não são signos arbitrários plenos de representações, comparados ao som verbal. Elas não enunciam conteúdos universais, mas somente a disposição a um sentimento que é introduzido por meio desses sons. Esse tipo de expressão ainda não pode ser denominado de arte. Para que a música seja reconhecida como tal, ela "deve colocar os sentimentos em relações sonoras determinadas e retirar a expressão natural de sua selvageria, de seu irromper rude e moderá-la" (HEGEL, 2002, p. 290). Na arte musical, o som deve ser inicialmente capacitado por meio de um tratamento artístico e, assim, acolher a expressão de uma vida interior (HEGEL, 2002). Para alcançar uma expressão determinada, para ser autônomo e ganhar vida, ele deve 
ser animado. Ele possui validade musical por meio de sua determinidade, em oposição ou em unidade com outros sons. Sua determinação acontece na relação com outros sons e por meio da duração temporal. Na música, ainda conforme Hegel (2002), é o tempo que domina. O ritmo vivifica a regra abstrata quando ressalta partes determinadas do compasso ou quando os põe em segundo plano. Os sons somente podem ser produzidos quando existe a vibração e quando um corpo que se coloca no espaço é posto em movimento oscilatório pela música. O material musical entra na música como uma duração temporal de seu movimento e não como uma forma espacial. No que concerne a essa espacialidade, a música não acolhe o movimento. Resta-lhe apenas o tempo para configurar a vibração do corpo. O som singular é fixado na temporalidade como sendo único e aí o tempo torna-se numerável. O tempo é o surgir e desaparecer ininterruptos de tais pontos temporais, um fluir uniforme. A música deve determinar precisamente o tempo, dar-lhe medida e ordenar o seu fluir de acordo com regras estabelecidas para essa medida. HEGEL (2002) afirma que a necessidade do tempo na música acontece porque ele está em extrema conexão com o si mesmo que, como interior, é objeto da música. O si mesmo deve tornar-se objetivo. O elemento universal dessa objetividade deve ser tratado de acordo com o princípio daquela interioridade. O eu não é a duração destituída de sustentação. Ele existe por meio do recolhimento e por meio do retorno a si mesmo. Ele se supera e se torna objeto. O compasso surge aí como uma das regulações em que diferentes partes temporais são reunidas em uma unidade e onde o eu faz para o si mesmo sua identidade consigo mesmo. O compasso é a regra e a medida da unidade temporal. Pode ser comparado com a arquitetura e possui a mesma tarefa que a regularidade tem para ela quando coloca colunas de idênticas alturas e espessuras na mesma distância, por exemplo. Em meio a determinados ritmos dos compassos surge também o acento, que faz com que cada compasso singular alcance um ritmo igualmente singular, com modos de articulação determinados. Rebatendo o ritmo do compasso e da melodia, instaura-se a síncope. Toda essa diversidade de relações e combinações temporais é rica de conteúdo. As diferentes combinações desses ingredientes podem relacionar-se a estados gerais de ânimo como, por exemplo, a lentidão na música com a melancolia.

Para o autor, a música move-se em um elemento feito primeiramente por meio da arte e volta-se para a mesma, devendo passar por uma prévia preparação significativamente mais complexa antes que alcance a produção de sons. Ela deve criar para si os meios usuais para o seu ressoar efetivo antes mesmo de sua existência. O som sai da espacialidade real como unidade ideal e se concretiza na coluna de ar retilínea ou curva, na delimitação de um canal fixo de madeira ou em uma corda de metal, entre outros materiais. Essa totalidade de instrumentos pode ser utilizada de diversos modos pela música, dependendo do caráter peculiar de cada um.

Fractal, Rev. Psicol., v. 30 - n. 1, p. 46-57, 2018
Outro elemento no universo musical é a relação entre sons singulares com outros sons, os intervalos. A série combinada de sons em sua mais simples sucessão em que um som remete a outro origina a escala. A diversidade das escalas, à medida que com seu som fundamental cada som se inicia de outro, cria a tonalidade, ou seja, as diversas relações entre notas. A base da determinidade dos sons é a relação numérica de suas vibrações. As relações sonoras não são escolhidas casualmente, elas devem conter uma necessidade interior para os lados de sua particularidade e de sua totalidade. Vê-se, assim, que para se tornar uma expressão adequada à arte, a música deve alcançar um conteúdo elaborado com base no ritmo, na melodia, na harmonia. Ela deve animar com riqueza os sentimentos e o ressoar que são desenvolvidos por meio de relações sonoras determinadas e, por meio dessa medida, elevar a simples expressão ao elemento feito primordialmente por meio da arte. Nela, o mero grito pode ser desenvolvido em uma série de sons e movimentos, cujo curso e alternância conservam-se pela harmonia e concluem-se na melodia. Para trabalhar o elemento objetivo, a música possui o elemento subjetivo. A interioridade subjetiva é o elemento constituinte da música. Nas palavras do autor, "música é espírito, alma, que ressoa imediatamente para si mesma, e se sente satisfeita ao se-perceber-a-si mesma" (HEGEL, 2002, p. 324). O próprio caráter do som já comporta um si mesmo, uma interioridade, que, como condição de possibilidade e com base na musicalidade universal, pode ser vivenciado na experiência com a obra de arte. Sendo essa a natureza da música, fica claro que é na própria obra de arte que se encontra a possibilidade de compreensão da música como fenômeno psicológico. Dessa forma, a obra de arte e a estética não prescindem da psicologia.

Essas ideias de base hegeliana estão contempladas na obra Psicologia da Arte, de Vigotski (2001, p. 21), que afirma que "sem um estudo psicológico especial nunca vamos entender que leis regem os sentimentos numa obra de arte". Nessa obra, ao criticar as duas principais tendências da estética, em sua época, dizia que a diferença entre elas passava pelo entendimento do caráter do objeto estético.

Uma dessas vertentes - a de cunho psicológico - concebia a estética como uma teoria do comportamento estético e considerava-a como uma espécie de psicologia do prazer estético e da criação artística. Assim, ou se estudava a psicologia do criador da obra ou a do seu receptor para o entendimento da obra de arte. Vigotski apontou vários erros nesse modo de tratar a estética. O primeiro seria o fato de começar pelo fim, ou seja, pelo prazer estético e pela avaliação, ignorando o próprio processo e não levando em conta que prazer e avaliação podem ser momentos secundários e suplementares do comportamento estético. O segundo erro seria a sua incapacidade de distinguir a emoção estética da emoção comum. Mas sua falha principal seria a falsa premissa de que a emoção estética complexa surge como a soma de prazeres estéticos particulares.

A outra vertente criticada pelo autor - a de cunho não psicológico - propunha-se a edificar uma base histórica e sociológica para o estabelecimento de uma teoria estética. 
Segundo propugnava, a arte só poderia ser objeto de estudo científico se fosse considerada como uma das funções vitais da sociedade em relação constante e permanente com os demais campos da vida social e como parte de um condicionamento histórico real. Nessa perspectiva, como tendência sociológica, o materialismo histórico procurou construir uma análise científica da arte tendo por base os princípios que eram aplicados ao estudo das formas e fenômenos presentes na vida social. Nesse terreno, a arte delimitava-se como ideologia, apresentando-se como superestrutura das relações de economia e de produção. Para o autor, o ponto fraco dessa vertente residia em que as condições sociais e econômicas não podem ser consideradas determinantes diretas da obra de arte. De outro modo, como compreender o fato de que a arte grega ainda continue a nos proporcionar uma reação estética?

Para o autor, as duas vertentes seriam complementares e não antagônicas, pois ele considera que a arte sistematiza o campo do sentimento do psiquismo do homem social. O psiquismo de um indivíduo particular é socialmente condicionado, não existindo, assim, fronteiras entre um e outro campo e nem diferença de princípios entre os processos de criação grupal e individual. Desse modo, o psiquismo de um indivíduo particular é o objeto da psicologia social. Tudo é social no homem, o que não significa que o psiquismo de um indivíduo seja inerente ao psiquismo de todos em uma sociedade. A arte possui um problema psicológico; as condições sociais determinam apenas indiretamente a natureza e o efeito da obra de arte. Os sentimentos suscitados por ela são socialmente condicionais. Sua forma possui a função de comunicar um sentimento social, ausente no objeto representado, mas conferido por ela. O comportamento estético do homem é ocasionado por mecanismos psicológicos que são determinados em seu funcionamento por razões de ordem sociológica. Os gostos e conceitos estéticos seriam possibilitados pela condição humana. A transformação dessa possibilidade em realidade seria determinada pelas condições que a cercam. Em nenhuma época as leis gerais da natureza psíquica do homem cessam. Em diferentes tempos, diversos materiais chegam às cabeças humanas e, assim, os resultados de sua elaboração não são os mesmos. Por isso, as leis psicológicas podem explicar a história da ideologia em geral e a história da arte, em particular. A psicologia de dada época possui uma raiz comum com as ideologias. Mas a argamassa é o psiquismo social e não a ideologia. Para compreender a arte, dessa forma, é necessária uma psicologia estética que estude a emoção, fenômeno que atravessa o percurso do desenvolvimento humano na arte.

\section{Música e arte}

A arte recolhe da vida o seu material, produzindo dele algo que ainda não está em suas propriedades: “A arte está para a vida como o vinho para a uva" (VIGOTSKI, 2001, p. 307). Um sentimento que é inicialmente individual torna-se social. Generaliza-se por meio da obra de arte. Ela é "[...] uma espécie de sentimento social prolongado ou uma técnica de sentimentos" (VIGOTSKI, 2001, p. 308, grifos do autor). Ela pode ser uma expressão direta da vida ou uma antítese dela; parte de determinados sentimentos vitais, reelaborando-os. É a catarse, pela transformação desses sentimentos em sentimentos opostos, que realiza essa elaboração: "A arte resolve e elabora aspirações extremamente complexas do organismo" (p. 309).

A música surgiu de um princípio geral do trabalho físico pesado, cuja meta é resolver pela catarse a tensão pesada gerada por ele. Quando arte e trabalho se separaram e a música passou a existir como atividade autônoma, na própria produção foi inserido o elemento que, antes, era constituído pelo trabalho. Perdendo sua relação direta com ele, a música conservou as mesmas funções, já que ainda deve sistematizar e organizar o sentido social, permitindo vazão e solução a tensões angustiantes.

A arte não se reduz a comunicar sentimentos. Seu fundamento biológico está em superar as paixões que não encontram vazão na vida comum. O comportamento é um processo de equilíbrio do organismo com o meio. Os processos de equilibração do organismo podem ser bastante confusos e complexos, quanto mais complexa e delicada se tornar a relação entre o organismo e o meio. Haverá aí a necessidade de dar vazão a energias não utilizadas para equilibrar a balança do homem com o mundo. A descarga de energia não utilizada faz parte da função da arte (VIGOTSKI, 2001). Para o autor, o organismo humano está de tal modo estruturado que muito mais atrações e estímulos são percebidos do que realizáveis. O organismo é um permanente campo de batalha. Para atingir equilíbrio, a arte é o veículo adequado. Além de percepção, ela também exige criação para que se supere criativamente o sentimento individual e encontre-se a própria catarse. Ela estrutura e ordena os sentimentos humanos. Mas mesmo onde existe apenas um homem com suas emoções pessoais, ainda aí existirá o social. Portanto, afirma Vigotski (2001, p. 315), “a arte é o social em nós [...]”. O seu efeito é sempre um efeito social, mesmo que realizando a catarse e arrastando as emoções para seu fogo purificador, bem como as comoções mais íntimas e vitalmente importantes de uma alma individual. Sobre isso, o autor afirma:

A refundição das emoções fora de nós realiza-se por força de um sentimento social que foi objetivado, levado para fora de nós, materializado e fixado nos objetos externos da arte, que se tornaram instrumentos da sociedade [...]. De igual maneira, a arte é uma técnica social do sentimento, um instrumento da sociedade através do qual incorpora ao ciclo da vida social os aspectos mais íntimos e pessoais de nosso ser [...] é a condensação da realidade [...]. Procura nos mostrar mais fenômenos vitais do que houve na vida que vivemos [...] o sentimento torna-se pessoal quando cada um de nós vivencia uma obra de arte, converte-se em pessoal, sem, contudo deixar de continuar social (p. 315).

Vigotski (2001) destacou a importância do papel que a arte desempenha na sociedade. Ela introduz a ação da paixão, rompendo o equilíbrio interno, modificando a vontade em um sentido novo, formulando e revivendo para a mente as emoções, vícios e paixões que teriam permanecido em estado indefinido e imóvel na sua ausência. A emoção ensejada pela obra de arte não é capaz de traduzir-se de modo imediato e direto em ação. É essa 
a diferença entre a emoção comum e a estética. O autor entende que o efeito da música, por exemplo, acontece por meio de abalos e deformações subterrâneas do posicionamento humano, manifestando-se insolitamente em determinado instante. Diz o autor que a música:

está mais isolada de nosso comportamento cotidiano, não nos leva diretamente a nada, mas cria tão somente uma necessidade imensa e vaga de agir, abre caminho e dá livre acesso a forças que mais profundamente subjazem em nós, age como um terremoto, desnudando novas camadas [...] Se a música não nos dita diretamente os atos que dela deveriam decorrer, ainda assim dependem de sua ação central, da orientação que ela destina à catarse típica, o tipo de forças que ela irá conferir à vida, o que ela liberta e o que recalca. A arte é antes uma organização do nosso comportamento visando ao futuro, uma orientação para o futuro, uma exigência que talvez nunca venha a concretizar-se, mas que nos leva a aspirar acima de nossa vida o que está por trás dela (VIGOTSKI, 2001, p. 320).

Dessas palavras pode-se inferir que, na obra de arte, estão presentes materiais que são combinados e enformados de diversos modos, com pontos de tensão e de relaxamento criados intencionalmente pelo compositor que possibilitam a reação estética. Essa elaboração artística independe de um estilo específico, não é patrimônio de um gênero particular de música. Pode ser encontrada em diversos tipos de discurso musical, no choro, na música popular, no samba, na música orquestral. O que importa é o tratamento estético dado ao material que é intencionalmente combinado de um modo particular que possibilita uma reação emocional de cunho estético.

Como em toda emoção, na reação estética há uma liberação de energia, uma catarse e "quanto maiores são esse dispêndio e essa descarga tanto maior é a comoção causada pela arte" (VIGOTSKI, 2001, p. 257). Todavia, a emoção estética é enigmaticamente distinta das demais emoções. Toda emoção prepara o organismo para a ação, energiza-o, move-o e é exatamente por isso que tem um valor de adaptação ao ambiente, um valor de sobrevivência. Ao energizar e preparar o organismo, incitando-o a agir, possibilita que surjam, de imediato, as reações adequadas à situação. Mas a arte tem uma função sutil ligada às emoções: "a emoção estética não provoca uma ação imediata, que se manifesta na mudança de orientação" e, além de não provocar ações, "ainda desabitua o indivíduo a realizá-las" (VIGOTSKI, 2001, p. 317). Eis aqui o ponto nevrálgico da sutil função da arte: ela serve como um meio de condicionar, culturalmente, o valor biológico das emoções. E faz isso não diretamente, mas trazendo-as para o plano da consciência, transformando-as em sentimentos e superando-os num ato catártico. Isso significa que não basta a presença de um sentimento, por mais autêntico que seja, para que se tenha a arte, ainda que a ele se junte a técnica e a maestria. É imprescindível o ato criador de superação do sentimento.

Assim, pode-se dizer que a arte permite superar paixões que não tiveram vazão na vida comum. Mas isso ainda não é tudo. O sentimento é particular, próprio de uma pessoa, o que não significa que não tenha caráter social, se não entendermos por social meramente o coletivo, a multiplicidade de pessoas. O plano social presentifica-se até mesmo onde existe apenas um homem e suas vivências pessoais. Logo, por meio da arte, a sociedade incorpora ao ciclo da vida social os aspectos mais íntimos e pessoais do nosso ser. Por isso, "quando a arte realiza a catarse e arrasta para esse fogo purificador as comoções mais íntimas e mais vitalmente importantes de uma alma individual", a sua ação é sempre social (VIGOTSKI, 2001, p. 315). É nesse sentido que se pode dizer que a arte promove o desenvolvimento do homem: ela é um meio de mudança qualitativa nas emoções humanas que, de um caráter elementar, biológico, superam-se, pela ação catártica, transformando-se em emoções de outra ordem, em emoções estéticas. Pelo que se disse, vê-se que a arte tem uma importância colossal na vida do homem.

É na própria obra que estão dispostas as condições para uma reação estética. A obra de arte é um sistema de estímulos organizados intencionalmente com o fim de suscitar uma reação estética. Então, analisando-se a estrutura e a configuração dos estímulos, pode-se recriar a estrutura dessa reação e, conforme diz Vigotski (2001, p. 26):

a resposta estética será absolutamente impessoal, ou seja, não pertencerá a nenhum indivíduo particular, nem refletirá nenhum processo psíquico individual em toda a sua concretude, pois isto será apenas um mérito dela. Esta circunstância nos ajuda a estabelecer a natureza da resposta estética em sua forma genuína, sem misturá-la com todos os processos casuais de que ela se cerca no psiquismo individual.

A psicologia estética implica, assim, um exame psicológico da obra, da possibilidade de reação estética. A emoção estética é uma síntese que somente na cultura é possível realizar-se. É próprio da arte, e somente dela, ser técnica do sentimento. Nenhuma outra atividade cultural faz isso.

Cada estilo musical, por exemplo, em cada cultura, possui uma organização interna, uma estrutura caracterizada pelo material que lhe dá forma. Para Vigotski (2001), material é aquilo que existe independentemente de uma narração, no contexto da vida, continuando assim, a existir fora da narração. Forma é a disposição desse material, de acordo com as leis de construção artística. A forma deve ser também entendida como um princípio ativo de elaboração e de superação do material em suas qualidades mais triviais e elementares. Não se trata, portanto, apenas de uma forma externa sonora, visual ou das demais formas sensórias que se abrem à percepção.

O material musical é o som, composto, por exemplo, entre outras coisas, pela intensidade, altura, duração e timbre, e a forma, segundo as leis de criação artística, a disposição desse material que, na história da cultura humana, constitui a história da música (ou da forma musical). Para Vigotski (2001), a correlação de determinadas partes do material faz parte da lei da arte. A disposição dos acontecimentos em uma narração, a unificação das frases, representações, imagens, ações, atitudes, réplicas estão todas subordinadas às leis dos encadeamentos artísticos, tal como os sons na melodia ou como as palavras no verso. A elaboração artística de um tema utiliza-se 
de vários recursos auxiliares, tendo um modo próprio de narrar os acontecimentos. A seleção dos fatos é aí de suma importância. Nessa escolha manifesta-se o ato criador. $\mathrm{O}$ artista escolhe os traços de que necessita nos acontecimentos. Ele elabora e reconstrói a matéria vital. A estrutura do discurso influencia até mesmo a respiração que é sintomática para provocar o efeito emocional. No campo emocional, o artista cria a reação estética.

Na obra de arte sempre existe uma contradição subjacente. Nela, há um material resistente que luta contra os empenhos do autor em dizer o que deseja. Superar tais propriedades é o trabalho na obra de arte. A ideia de harmonia entre forma e conteúdo, afirmada durante séculos pelos especialistas em estética, é apontada por Vigotski (2001) como um equívoco. A forma combate o conteúdo e o supera em uma contradição dialética. Esse é o sentido psicológico da reação estética. O direcionamento da atenção garante o isolamento dos estímulos reais que são necessários para a reação estética. Nisso, o universal transforma-se em particular.

Apesar de enformada por seu material específico, cada música, como obra, seja ela considerada obra de arte (no sentido estrito do termo) ou não, carrega, em sua anatomia, para utilizar as palavras de Vigotski (2001), seu sentido psicológico que atravessa o tempo histórico. No sistema tonal da música do século XVIII, por exemplo, em um encadeamento I-IV-V-I (tônica, subdominante, dominante e tônica), a sequência finalizada na tônica, na cultura ocidental, costuma ser previamente esperada, pois nela há um relaxamento da tensão criada pela subdominante e pela dominante. O sentido psicológico que constitui tal encadeamento está presente na própria música. É ela que carrega em sua anatomia a tensão e o relaxamento. Essa anatomia psicológica pode ser encontrada na própria obra, independentemente do seu criador ou do seu receptor. Isso porque o material e o seu enformamento encontram-se na vida do homem cultural, como afirma Vigotski (2001).

Na maior parte das músicas, existem sentidos que se referem à experiência da vida em geral e que se afirmam por meio da qualidade dos sons. A textura, o timbre, a altura e suas combinações, entre outros materiais sonoros, propiciam um campo de significados e sentidos que fazem parte das convenções sociais, mas são inerentes à música. Para se transformar em um objeto cultural, o contexto musical passa por uma legitimação histórica e social (GREEN, 2005). Para essa autora, não se pode separar a experiência de significados inerentes à música da consciência do contexto social que acompanha sua produção e recepção. Também há, de acordo com ela, constituintes não musicais da produção e recepção de uma música, mas que, de alguma forma, são relacionados a ela. Pela complexidade da cultura humana, é muito difícil, à primeira vista, separar os dois significados. $\mathrm{O}$ primeiro ocorre em uma relação de som para som e o segundo, entre som e não-som. "Música não é meramente um sintoma de nossas práticas e significados musicais, mas esse ato volta para nós por meio dessa capacidade de influenciar nossas crenças, valores, sentimentos e comportamentos" (GREEN, 2005, p. 80).
Também para Elliot (2005), os padrões musicais são sons organizados que têm por base práticas e princípios sociais. Ao delimitar os materiais musicais com os quais vai trabalhar, cada compositor organiza-os e seleciona-os intencionalmente com base em algum referencial. As atividades musicais são, assim, eventos sônico-sociais. A escolha de uma organização musical atravessa gerações de pessoas. São convenções, padrões musicais desenvolvidos em cada cultura que carregam em si as diversas emoções humanas. Os sons musicais possuem referência histórica. São sons musicais e não somente sons. Fazem parte de tradições históricas artístico-musicais. As emoções, para o autor, também são materiais musicais e pertencem à dimensão do significado. $\mathrm{O}$ produto musical inclui representações de pessoas, lugares, coisas e sentimentos. Agrega também conhecimentos, crenças e valores.

Em cada música, diversos elementos podem ser utilizados pelo compositor, tais como crescendo graduais, variações rítmicas ou mudanças de timbres e modificam a experiência emocional. Um estado de expectativa pode ser gerado pelas possibilidades que se concretizam na obra e que criam, de acordo com as circunstâncias, um sistema ordenado de crenças e de atitudes. Se outros estímulos são apresentados, também pode haver uma reorganização, uma reavaliação dos estímulos por parte do receptor.

De acordo com Meyer (1984), o padrão emocional na experiência estética pode ser considerado como progressão do alívio da tensão. Trata-se, então, sempre de um alívio procurado em um dado contexto de tensão. Para o autor, esse tipo de experiência em relação ao suspense é muito similar ao mesmo tipo de experiência na vida real. O significado e a comunicação não podem ser entendidos ou considerados fora do contexto cultural ao qual pertencem. Há a mesma situação estímulo, tanto na vida real quanto na música, ou seja, uma situação de ignorância sobre o futuro, a consciência da impotência individual, bem como a inabilidade de agir diante dos eventos futuros desconhecidos. Assim, há uma analogia direta do suspense musical com a experiência de suspense, em geral. $\mathrm{O}$ autor afirma que a experiência da emoção estética na música é específica e diferenciada em termos de estímulos extramusicais. Para ele, o indivíduo que responde ao estímulo musical possui ou simula experiências afetivas que podem ser comunicadas ou não a outros por meio de seu comportamento e isso pode gerar uma espécie de empatia ao mesmo estímulo devido às experiências similares entre indivíduos, criando uma espécie de comunicação emocional estética. Esse tipo de comunicação liga-se diretamente a experiências vividas nas diversas culturas e aos seus grupos específicos. O estabelecimento de uma comunicação das emoções por meio da arte e particularmente da música acontece, então, devido a uma espécie de seleção cultural que determina composições e padrões estéticos emocionais válidos de serem vividos e compartilhados.

As abordagens de Meyer, Green e Elliot, entretanto, apesar de avaliarem a importância da obra de arte para análise de seu significado, do material e da forma, falham na compreensão de sua relação com as pessoas. Parecem considerá-la como uma relação de contágio das emoções, já 
que generalizam os padrões estéticos emocionais. Deixam de considerar justamente o passo adiante dado por Vigotski (2001), ou seja, como a arte e as emoções transformam-se dialeticamente na história cultural e como sua relação, sua nova síntese, engendrada na cultura, é de natureza diferenciada. Deixam de considerar, ainda, a possibilidade de desenvolvimento das emoções, que não são emoções periféricas, mas de ordem superior. Não efetuam a devida análise da qualidade das emoções estéticas e o seu papel na experiência artística e na vivência consciente e particular das emoções para o desenvolvimento do psiquismo.

$\mathrm{Na}$ anatomia de uma música, um padrão de expectativa gerado em sua estrutura, uma progressão, por exemplo, pode ser considerado como uma norma. Um desvio disso pode ser considerado como um estímulo emocional. Desse modo, é difícil pensar em um ouvinte passivo, um mero espectador sem emoções próprias e singulares. $\mathrm{O}$ padrão emocional que acontece na arte, como já dito anteriormente, não é um padrão natural, de caráter biológico. É um fenômeno culturalmente desenvolvido. Daí porque se torna importante o estudo da emergência e desenvolvimento ontogenético da reação emocional estética.

O presente trabalho buscou examinar, ainda que de modo exploratório, a emergência da reação estética da criança na atividade musical. Ou seja, pretendeu-se identificar emoções vividas por crianças de diferentes idades, na situação de ouvinte de uma obra musical e o modo como analisavam suas próprias vivências.

\section{Método}

\section{Participantes}

Participaram do estudo um total de nove crianças, agrupadas em três grupos de três crianças com idade variando de 7 a 12 anos. Num agrupamento, havia uma menina (Yara) de oito anos de idade e dois meninos: André, de oito anos e Luis, de 10 anos. Num segundo, estavam um menino (Daniel, de 9 anos) e duas meninas (Anelice e Elena, de 12 e 10 anos, respectivamente). Finalmente, no terceiro agrupamento encontravam-se Raquel, de 9 anos, Joaquim, de 7 anos e Caio, de 9 anos. O agrupamento das crianças foi feito com base em razões de ordem prática. Os nomes indicados são fictícios.

\section{Procedimento}

A coleta de dados foi realizada em cinco sessões de audição musical em que as crianças ouviam trechos musicais previamente selecionados pelos pesquisadores e, em seguida, conversavam com eles sobre os trechos ouvidos, ou seja, cada sessão consistia de uma audição com diálogo. Esse diálogo era gravado em vídeo.

Em cada sessão, primeiramente, os pesquisadores esclareciam às três crianças de cada grupo que ouviriam um trecho de uma obra musical e, depois, conversariam sobre ele. Então, deixavam-nas escutarem o trecho previamente selecionado, antes de começarem a conversar. Os pesquisadores permitiam-lhes ouvir o trecho quantas vezes quisessem, mesmo que fosse necessário interromper a conversa já iniciada. Essa conversa versava sobre os seguintes pontos, em todas as sessões:
1. Indicar se gostaram ou não da música;

2. Indicar a parte de que mais gostaram, a de que menos gostaram e dizer o porquê;

3. Indicar o que sentiram ao ouvir a música;

4. Indicar a parte da música que provocou aquele sentimento;

5. Indicar o que, na parte destacada, provocava o sentimento referido;

6. Indicar se acreditavam que quem fez a música queria que as pessoas sentissem o que elas mesmas sentiram;

7. Indicar como achavam que o compositor fez para provocar o que sentiram;

8. Indicar se acreditavam que, quando os músicos compõem uma obra, eles querem que as pessoas que vão ouvi-la sintam alguma coisa;

9. Se as crianças respondiam sim à última questão, perguntava-se: como os compositores conseguem isso?

10. Se respondiam que não, perguntava-se: Por que acham que um músico compõe uma música?, Por que e para que as pessoas ouvem música?

Para cada uma das sessões, era apresentado trecho de uma música que induzisse uma emoção: 1. Alegria: $1 x$ 0, de Jacob do Bandolim; 2. Medo: Rocky Mountains, de Wendy Carlos e Rachel Elkind; 3. Raiva: Hell, da banda Vendo 147; 4. Calma: um trecho de um canto gregoriano, e 5.Tristeza: Tristesse, de Chopin. A ordem de apresentação dos trechos musicais foi a mesma para todos os grupos.

\section{Resultados}

Para exame dos resultados, os diálogos mantidos com as crianças foram transcritos e, ao ler essas transcrições, identificavam-se as ações verbais das crianças em relação ao trecho musical que ouviram. Fazendo assim, foi possível criar-se um protocolo de ações que, por sua vez, foram agrupadas em três campos, conforme sua complexidade. $\mathrm{O}$ primeiro campo contém as ações mais simples das crianças (identificadas com o número 1) e, por isso, foi denominado de Campo da atividade pré-musical. As ações desse campo revelam que a atenção da criança não está voltada para a peça musical em si, mas a aspectos fenotípicos da performance musical ou externos a ela. A peça musical é tratada pela criança de modo global, daí porque essas ações não evidenciam qualquer habilidade analítica da mesma. Fazem parte desse campo as seguintes ações:

1a) trata a peça musical de modo homogêneo, não reconhecendo suas partes distintas; 1b) aponta detalhes da execução musical de modo descontextualizado; fazendo simulacro de ação de outrem, anteriormente observada; 1c) indica aspectos "fenotípicos" da atividade musical, no lugar dos "genotípicos"; 1d) informa sobre sinais convencionais da linguagem musical, numa clara repetição de algo anteriormente ouvido; 1e) identifica incorretamente instrumentos presentes na execução musical; 1f) imita, com gestos, o modo de tocar um determinado instrumento; $1 \mathrm{~g}$ ) aponta de modo generalizado emoção ensejada pela peça musical; 1h) associa movimentos corporais ao tipo de emoção ensejada pela peça musical; 
1i) relaciona ritmo a uma atividade corporal difusa; $1 \mathrm{j}$ ) atribui função lúdica à peça musical; 1k) atribui função utilitária à atividade musical; 1L) aponta incorretamente emoção ensejada pela peça musical; $1 \mathrm{~m}$ ) identifica incorretamente e de modo geral altura da peça musical; 1n) associa, incorretamente, timbre a emoção específica.

O segundo grupo, denominado Campo da atividade musical ingênua, contém ações que evidenciam alguma habilidade analítica da peça musical (identificadas com o número 2), mas ainda de forma incipiente. Essas ações mostram que a atenção da criança já começa a voltar-se para aspectos da própria peça musical - e não externos a ela, como no caso do Campo da atividade pré-musical. Contudo, ela ainda realiza uma análise incorreta dos elementos que compõem a peça musical. Esse campo contém as seguintes ações:

2a) associa ritmos diferentes a diferentes atividades corporais; $2 b$ ) relaciona peça musical com vivência anterior; 2c) indica preferência por peça musical em função do ritmo apenas; 2d) relaciona, incorretamente, timbre com emoção; 2e) associa, incorretamente, andamento da peça musical com emoção; 2f) identifica, incorretamente, ritmo da peça musical; 2g) identifica, de modo incipiente, elementos da composição musical; 2h) associa, incorretamente, ritmo a emoção.

Finalmente, o terceiro grupo, denominado de Campo da atividade de análise musical, contém ações (identificadas com o número 3) que revelam que a criança, efetivamente, já realiza alguma análise dos elementos que compõem a peça musical:

3a) identifica corretamente instrumentos presentes na execução musical; 3b) aponta corretamente emoção ensejada pela peça musical; 3c) identifica corretamente an-

\begin{tabular}{|c|c|c|c|c|c|}
\hline \multirow[t]{2}{*}{ Participantes } & \multicolumn{5}{|l|}{ Sessão } \\
\hline & 1 & 2 & 3 & 4 & 5 \\
\hline Yara & $\begin{array}{l}1 \mathrm{a}, 1 \mathrm{~b}, 1 \mathrm{c}, \\
1 \mathrm{~d} 1 \mathrm{e}, 1 \mathrm{f}, \\
1 \mathrm{~g}, 1 \mathrm{~h}, 1 \mathrm{j}, \\
1 \mathrm{k} \\
2 \mathrm{a}, 2 \mathrm{~b} \\
3 \mathrm{a}, 3 \mathrm{~b}\end{array}$ & $\begin{array}{l}1 \mathrm{f}, 1 \mathrm{~g}, 1 \mathrm{j}, 1 \mathrm{k}, \\
1 \mathrm{~L}, 1 \mathrm{~m} \\
2 \mathrm{~b}, 2 \mathrm{c}, 2 \mathrm{~d} \\
3 \mathrm{a}, 3 \mathrm{~b}, 3 \mathrm{c}, 3 \mathrm{~d}, \\
3 \mathrm{f}, 3 \mathrm{~g}\end{array}$ & $\begin{array}{l}\text { 1a, 1b, 1f, 1g, } \\
1 \mathrm{i}, 1 \mathrm{k}, 1 \mathrm{~L} \\
2 \mathrm{~b} \\
3 \mathrm{a}\end{array}$ & - & - \\
\hline Luís & $\begin{array}{l}1 \mathrm{a}, 1 \mathrm{c}, 1 \mathrm{~g}, \\
1 \mathrm{j} \\
2 \mathrm{~b} \\
3 \mathrm{a}, 3 \mathrm{~b}\end{array}$ & $\begin{array}{l}1 \mathrm{f}, 1 \mathrm{j}, 1 \mathrm{k}, 1 \mathrm{~L} \\
2 \mathrm{~b}, 2 \mathrm{~d} \\
3 \mathrm{a}, 3 \mathrm{~b}, 3 \mathrm{e}, 3 \mathrm{f}\end{array}$ & $\begin{array}{l}\text { 1a, 1b, 1f, 1i, } \\
1 \mathrm{j}, 1 \mathrm{~L} \\
3 \mathrm{a}, 3 \mathrm{c}, 3 \mathrm{~d}\end{array}$ & $\begin{array}{l}1 \mathrm{a}, 1 \mathrm{~h}, 1 \mathrm{j}, 1 \mathrm{k}, \\
1 \mathrm{~L}, 1 \mathrm{~m} \\
2 \mathrm{~b}, 2 \mathrm{~d}, 2 \mathrm{e} \\
3 \mathrm{a}, 3 \mathrm{c}, 3 \mathrm{e}\end{array}$ & $\begin{array}{l}1 \mathrm{a}, 1 \mathrm{~g}, 1 \mathrm{i}, 1 \mathrm{j}, \\
1 \mathrm{~L}, 1 \mathrm{~m} \\
2 \mathrm{~d} \\
3 \mathrm{a}, 3 \mathrm{c}, 3 \mathrm{f}, 3 \mathrm{~h} \\
3 \mathrm{i}, 3 \mathrm{j}\end{array}$ \\
\hline André & $\begin{array}{l}1 \mathrm{c}, 1 \mathrm{e}, 1 \mathrm{~g}, \\
1 \mathrm{j} \\
2 \mathrm{~b} \\
3 \mathrm{~b} \\
\mathrm{Re}\end{array}$ & - & - & - & - \\
\hline Daniel & $\begin{array}{l}1 \mathrm{f} \\
2 \mathrm{~b}, 2 \mathrm{f} \\
3 \mathrm{a}, 3 \mathrm{~b}, 3 \mathrm{j}, \\
3 \mathrm{k}\end{array}$ & $\begin{array}{l}1 \mathrm{~L} \\
2 \mathrm{~b} \\
3 \mathrm{~b}\end{array}$ & $\begin{array}{l}1 \mathrm{e}, 1 \mathrm{~L} \\
3 \mathrm{a}, 3 \mathrm{~b}, 3 \mathrm{c}\end{array}$ & $\begin{array}{l}1 \mathrm{~L} \\
3 \mathrm{e}, 3 \mathrm{f}, 3 \mathrm{i}, 3 \mathrm{~L}\end{array}$ & $1 \mathrm{i}, 1 \mathrm{k}$ \\
\hline Elena & $\begin{array}{l}1 \mathrm{e}, 1 \mathrm{~h} \\
2 \mathrm{~b}, 2 \mathrm{~d} \\
3 \mathrm{a}, 3 \mathrm{~b}, 3 \mathrm{f}\end{array}$ & $3 b, 3 f, 3 h$ & $\begin{array}{l}1 \mathrm{j}, 1 \mathrm{k}, 1 \mathrm{~L} \\
3 \mathrm{a}, 3 \mathrm{~b}, 3 \mathrm{c}, 3 \mathrm{f}\end{array}$ & $\begin{array}{l}2 \mathrm{f} \\
3 \mathrm{a}, 3 \mathrm{~b}, 3 \mathrm{c}, 3 \mathrm{~d}, \\
3 \mathrm{e}, 3 \mathrm{f}, 3 \mathrm{i}, 3 \mathrm{~L}\end{array}$ & $\begin{array}{l}1 \mathrm{~g}, 1 \mathrm{~L} \\
2 \mathrm{~d} \\
3 \mathrm{a}, 3 \mathrm{c}\end{array}$ \\
\hline Anelice & $3^{a}$ & - & $3 c, 3 f$ & - & $3 a$ \\
\hline Caio & $\begin{array}{l}\text { 1a, 1c, } 1 \mathrm{e}, \\
1 \mathrm{f}, 1 \mathrm{~g} 1 \mathrm{j}, \\
1 \mathrm{~L}, 1 \mathrm{~m}, 1 \mathrm{n} \\
2 \mathrm{c} \\
3 \mathrm{a}, 3 \mathrm{~b}, 3 \mathrm{c}, \\
3 \mathrm{~d}, 3 \mathrm{f}, 3 \mathrm{i}, \\
3 \mathrm{j}\end{array}$ & $\begin{array}{l}1 \mathrm{e}, 1 \mathrm{~g}, 1 \mathrm{~h} \\
2 \mathrm{~b} \\
3 \mathrm{~b}, 3 \mathrm{c}, 3 \mathrm{~d}, 3 \mathrm{f}, \\
3 \mathrm{i}, 3 \mathrm{j}\end{array}$ & - & $\begin{array}{l}1 \mathrm{j} \\
2 \mathrm{~b} \\
3 \mathrm{c}\end{array}$ & $\begin{array}{l}1 \mathrm{~L} \\
2 \mathrm{~g} \\
3 \mathrm{~b}, 3 \mathrm{c}, 3 \mathrm{e}, 3 \mathrm{j}\end{array}$ \\
\hline Joaquim & $\begin{array}{l}1 \mathrm{a}, 1 \mathrm{e}, 1 \mathrm{~g}, \\
1 \mathrm{j} \\
2 \mathrm{~b} \\
3 \mathrm{a}, 3 \mathrm{~b}, 3 \mathrm{j}\end{array}$ & $\begin{array}{l}1 \mathrm{~h} \\
3 \mathrm{~b}\end{array}$ & - & $\begin{array}{l}2 \mathrm{~g} \\
3 \mathrm{~b}, 3 \mathrm{f}\end{array}$ & $1 \mathrm{~L}$ \\
\hline Raquel & $\begin{array}{l}1 \mathrm{c}, 1 \mathrm{e}, 1 \mathrm{~g}, \\
1 \mathrm{j} \\
2 \mathrm{~h} \\
3 \mathrm{a}, 3 \mathrm{~b}, 3 \mathrm{f}, \\
3 \mathrm{i}\end{array}$ & $\begin{array}{l}\text { 1b,1e,1h, 1j, } \\
1 \mathrm{~L} \\
2 \mathrm{~b} \\
3 \mathrm{c}\end{array}$ & - & $\begin{array}{l}1 \mathrm{j} \\
3 \mathrm{~b}, 3 \mathrm{i}\end{array}$ & $\begin{array}{l}1 g, 1 j, 1 \mathrm{~L} \\
3 \mathrm{~b}\end{array}$ \\
\hline
\end{tabular}

da peça musical com emoção; 3g) atribui à música a produção de uma reação estética no ouvinte; 3 h) relaciona, corretamente, altura da peça musical com emoção; 3i) identifica intenção estética do compositor; $3 \mathrm{j}$ ) associa, corretamente, ritmo a emoção; 3k) identifica, corretamente, características do ritmo; $3 \mathrm{~L}$ ) relaciona, corretamente, volume da peça musical com emoção.

Por vezes, não era possível identificar a ação da criança pelo fato de ter apresentado uma resposta evasiva (re). A Tabela 1 contém a distribuição das ações de cada criança, nas cinco sessões de audição musical com diálogo.

Tabela 1: Ocorrência das categorias de ação para cada criança, nas cinco sessões de audição com diálogo. damento da peça musical;

3d) identifica corretamente altura predominante da peça musical; 3e) relaciona corretamente andamento da peça musical com emoção ; 3f) relaciona corretamente timbre 
Vê-se pela Tabela 1 que, no grupo como um todo, há um claro predomínio das ações do campo da atividade pré-musical, embora uma das crianças, o Luís, tenha realizado grande parte das ações do terceiro grupo, considerando-se as sessões como um todo.

Na primeira sessão de audição, Yara demonstrou, inequivocamente, que se encontrava no campo da atividade pré-musical. Para ela, a música, no que diz respeito à sua estrutura, era um todo homogêneo (ao ser indagada sobre a parte de que mais gostara, respondeu que era "tudo a mesma coisa"), que serve para divertir (função lúdica) ou para aprender (função utilitária). Procurava demonstrar às pesquisadoras, o tempo todo, que entendia de música e, ao fazer isso, deixava bastante claro que sua atenção voltava-se, predominantemente, para aspectos fenotípicos da atividade e da performance musical. Por exemplo, ao responder ao questionamento da pesquisadora a respeito do que o compositor fazia para realizar, na estrutura da obra que compôs, uma determinada intenção estética, disse: "ele bota num caderninho, aí pega os instrumentos e toca e vê, no caderninho". Ou seja, os aspectos visuais, fenotípicos, da atividade musical são os que despertavam sua atenção. Ainda, com a mesma intenção de demonstrar seu entendimento musical, espontaneamente, afirmou: "quando toca o violino tem alguns que não estão afinados e outros que estão afinados. E tem que fazer afinação pra fazer música. Tem música clássica que significa pra botar o violino mais ou menos afinado". Além de, nesse caso, ter identificado erroneamente o instrumento (era bandolim e não violino), parece também revelar o quanto o seu comportamento imita ações que observou de outras pessoas. Esse é o caso também quando informa sobre sinais convencionais da linguagem musical, numa clara repetição de algo que já ouvira: "Tia, sabia que quando a pessoa mexe o pauzinho e abaixa, quer dizer que é pra abaixar o volume?" Para Yara, nessa sessão, a música é diretamente vinculada a movimentos corporais: tanto o ritmo quanto a emoção que propicia associam-se a movimentos corporais difusos. Embora, algumas vezes, tenha indicado, de modo generalizado, um estado subjetivo gerado pela música que acabara de ouvir ("felicidade"), com frequência, apontou com precisão que a emoção ensejada pela música era alegria. Aliado ao fato de reconhecer corretamente instrumentos de percussão (espontaneamente, informou que na música executada havia pandeiro, mas não tambor) e de associar ritmos diferentes a diferentes atividades corporais, isso parece significar possibilidades importantes, mesmo que rarefeitas, de desenvolvimento da reação estética de Yara. Efetivamente, isso é o que se verifica na segunda sessão de audição, quando as ações do campo da atividade musical ingênua e da análise musical, somadas, predominam. Ela realiza menos ações que denotam que sua atenção volta-se, principalmente, para aspectos fenotípicos da execução musical e, embora, no início, tenha identificado incorretamente a emoção ensejada pelo trecho que ouvira, ao final da sessão, passou a reconhecê-la, corretamente. Além disso, demonstrou prestar atenção a elementos que são parte da execução musical, tais como andamento, altura e timbre, bem como relacionar a qualidade do timbre a uma emoção específica, ainda que, algumas vezes, de modo incorreto. Na terceira sessão, contudo, há certa regressão: predominam, nas ações de Yara, aquelas do campo da atividade pré-musical. Ela volta a tratar a peça de um modo homogêneo, sem reconhecer elementos que a compõem, a realizar simulacros ("porque eu sinto que, no começo, ele tá fazendo tan tan tan e tá indo um pouco rápido e um pouco devagar. Aí, não é muito rápido porque o começo das músicas não é muito rápido, não pode começar, nunca existiu começar muito rápido"), a apontar, de modo generalizado, a emoção ensejada pela peça musical ou a identificá-la incorretamente. Todavia, parece haver uma conquista: ela não mais identificou, incorretamente, instrumentos presentes na peça musical. Todas as vezes em que referiu-se a eles, fez de modo correto. Yara não compareceu às duas últimas sessões de audição, impedindo, assim, que se possa afirmar com segurança que essa e outras possíveis conquistas estavam consolidadas. Em síntese, pode-se dizer que, de um modo geral, a atividade musical de Yara encontra-se fortemente situada no campo da atividade pré-musical, mas apresenta bons indícios de possibilidade de avanços para outros campos. Tudo indica que, para ela, as sessões de audição com diálogo podem favorecer o desenvolvimento de sua reação estética.

Luís, por sua vez, na primeira sessão, mostra-se bastante parcimonioso em suas ações. Todo o tempo, manteve-se restrito a sete tipos de ação. Destas, quatro situam-se no campo da atividade musical ingênua. Ele começou apontando, de modo generalizado, a emoção ensejada pela peça musical, tratando esta de modo homogêneo, atribuindo-lhe uma função lúdica e indicando aspectos fenotípicos da mesma. Entretanto, os outros três tipos de ação que apresentou (uma no campo da atividade musical ingênua - "porque, na capoeira, eu toquei. Fez eu lembrar" - e duas no da atividade de análise musical) mostram que ele já adentrava zonas mais avançadas de desenvolvimento na atividade musical. Por exemplo, ele já percebia que a música é parte de uma vivência e pode, por isso, tornar-se instrumento de recordação. Talvez seja devido a isso que conseguia identificar, corretamente, a emoção ensejada pela peça musical ouvida e instrumentos presentes na mesma. Na segunda sessão, Luís ainda apresentava ações no campo da atividade ingênua. Ele atribuía função lúdica e utilitária à atividade musical e ora associava, incorretamente, emoção específica à peça musical, ora fazia isso de modo generalizado. Começava a apresentar, ainda que incorretamente, ações precursoras de análise, quando, num primeiro momento, associou, mesmo que de modo equivocado, o timbre com uma determinada emoção. Posteriormente, conseguiu fazer essa associação corretamente, fazendo o mesmo com relação ao andamento da peça musical e indicando, também acertadamente, a emoção por ela ensejada. Esse mesmo padrão de ações foi reproduzido na terceira e na quarta sessão, havendo apenas pequenas variações no tipo de ação que apresentou. Ou seja, até a quarta sessão, Luís demonstrava, com clareza, encontrar-se no campo da atividade musical ingê- 
nua, com algumas poucas incursões no terceiro campo de atividade. Todavia, na quinta e última sessão, houve uma mudança digna de registro de seu padrão de ações. Estas distribuíram-se, quase que equitativamente, entre o primeiro e o terceiro campo. Ainda que demonstrasse muitas ações do grupo 1, as que apresentou, no grupo 3, denotam que sua atividade de análise da peça musical encontrava-se, indubitavelmente, em processo de desenvolvimento. Tudo parece indicar, assim, que a audição com diálogo, para Luís, teve um papel impulsionador de seu desenvolvimento. Do mesmo modo que para Yara, as sessões de audição com diálogo foram propiciadoras do desenvolvimento da atividade musical de Luís.

A grande maioria das ações apresentadas por André, na única sessão a que compareceu, pertence ao campo da atividade pré-musical. No campo 3, ele apontou corretamente a emoção ensejada pela peça musical. André mostrou-se bastante impaciente, perguntando sempre aos pesquisadores sobre o tempo que restava para concluí-la. Por várias vezes, respondeu evasivamente às questões que lhe eram dirigidas ou denotava displicência ao responder. Assim, via-se claramente que, por alguma razão, a atividade, tal como era apresentada a ele, estava completamente fora de seus interesses ou, ainda, talvez, ela estivesse muito aquém de suas possibilidades. Desse modo, qualquer interpretação acerca de seu desempenho na atividade carece de precisão.

Comparadas às outras três crianças, as deste agrupamento apresentam um desempenho bastante diferenciado. Sem exceção, mostram-se, predominantemente, no terceiro campo da atividade musical. Vale lembrar que Yara e André tinham 8 anos de idade e Luís, 10, quando da realização das sessões. Por sua vez, Anelice tinha 12, Elena, 10 e Daniel, 9 anos de idade. À primeira vista, parece que a diferença de idade explicaria os distintos desempenhos. Todavia, um exame mais acurado mostra que isso não é verdadeiro. Anelice, a mais velha de todas as crianças, compareceu a todas as sessões, mas, na segunda e na quarta, não apresentou nenhuma ação dos três campos. A pesquisadora, insistentemente, dirigia perguntas a ela e incentivava-a a se pronunciar. Entretanto, ela quase sempre era evasiva ou não respondia. Embora todas as suas ações pertencessem ao terceiro campo da atividade musical, elas são tão poucas e infrequentes que não autorizam qualquer conclusão a respeito do desenvolvimento de sua atividade musical. Restam, assim, para comparar, as duas outras crianças: Elena, com a mesma idade de Luís e Daniel, mais novo que ele. Logo, a diferença de desempenho não pode ser atribuída à idade e deve encontrar-se, talvez, na própria experiência musical anterior das crianças. Seja como for, vale a pena ressaltar que o fato de essas diferenças tornarem-se evidentes mostra que o instrumento para análise e interpretação dos dados obtidos é adequado aos fins para os quais foi criado.

Já na primeira sessão, Daniel demonstrou encontrar-se, predominantemente, no campo da atividade de análise musical. Apesar de ter apontado, incorretamente, o ritmo da peça musical, ele identificou, corretamente, instrumentos presentes na execução e a emoção que ensejava ("eu acho que ele queria passar alegria com essa música"), estabelecendo relação desta com o ritmo. Além disso, demonstrou ser capaz de identificar características do ritmo. $\mathrm{Na}$ segunda e na quinta sessão, foram bastante escassas as ações que realizou, mas na terceira e na quarta, tomadas em conjunto, vê-se que houve, nitidamente, um predomínio de ações do terceiro campo. Ele identificou, corretamente, os instrumentos, o andamento e a emoção ensejada pela peça musical, relacionando esta a andamento, timbre e volume, além de demonstrar que reconhecia haver uma intenção estética do compositor, ao compor sua peça.

Das três crianças, Elena foi, sem dúvida, a que demonstrou encontrar-se mais firmemente no campo da atividade de análise musical. Apesar de, algumas vezes, ter errado na identificação de instrumentos presentes na peça musical e da emoção que ensejava, de ter atribuído função lúdica e utilitária à atividade musical e de apontado, equivocadamente ou de modo generalizado, a emoção ensejada pela peça musical - ações essas pertencentes ao campo da atividade pré-musical -, suas ações concentraram-se, marcadamente, no terceiro campo. Ela demonstrou conseguir identificar instrumentos presentes na peça musical, a emoção por ela ensejada e sua relação com o andamento, altura e volume, além de reconhecer a existência da intenção estética do autor da peça. Foi na quarta sessão que aconteceu a maior concentração de ações do terceiro campo, o que parece indicar que o desenvolvimento da reação estética de Elena foi, de algum modo, bastante impulsionado pelas sessões de audição com diálogo.

As crianças do terceiro agrupamento, de um modo geral, pareciam encontrar-se numa fase intermediária em relação às dos outros dois grupos. Confirma-se, aqui, que o fator idade não foi o determinante das diferenças entre as crianças, uma vez que, nesse grupo, duas crianças tinham 9 anos (Raquel e Caio) e uma 7 (Joaquim), na ocasião da coleta de dados. É importante esclarecer que, por problemas de ordem técnica, houve perda dos registros da terceira sessão e ela não pode ser refeita devido à impossibilidade de comparecimento das crianças.

Caio apresentou uma concentração ligeiramente maior de ações no campo da atividade pré-musical, comparativamente às do terceiro campo. Raquel mostrou o inverso e, para Joaquim, os dois campos foram equivalentes. Na primeira sessão de Caio, houve ligeiro predomínio de ações do primeiro campo, quadro que se modificou a partir daí, até a última sessão. Naquela sessão, ele, por vezes, tratou a peça musical como um todo homogêneo, destacou seus aspectos fenotípicos, identificou, de modo incorreto, instrumentos presentes na execução musical e ou indicou, de modo generalizado, emoção por ela ensejada, ou identificou-a incorretamente. Também cometeu erros na identificação da altura da peça e ao associar timbre a uma emoção específica. Em outros momentos, todavia, identificou corretamente os instrumentos presentes na execução, a emoção ensejada pela peça musical, o seu andamento e altura predominante, relacionando corretamente timbre e ritmo com emoção e reconhecendo corretamente intenção estética do autor. $\mathrm{Na}$ segunda sessão, ele manteve quase esse mesmo pa- 
drão de ações do campo da atividade de análise musical e, ao mesmo tempo, diminuiu as do campo da atividade pré-musical, denotando um importante avanço em sua atividade musical. Essa última configuração manteve-se na quinta sessão (na quarta, ele apresentou pouquíssimas ações), permitindo afirmar-se que as sessões de audição com diálogo, efetivamente, contribuíram para o desenvolvimento da reação estética de Caio.

As ações de Joaquim distribuíram-se quase homogeneamente entre o primeiro e o terceiro campo. Ele foi muito parcimonioso em suas ações, talvez, por ser a criança mais nova do grupo, o que dificulta um pouco a interpretação de seu desempenho. Na primeira sessão, ele tratou a peça musical como um todo homogêneo; às vezes, indicou, incorretamente, o instrumento presente na peça, às vezes, corretamente; em certas ocasiões, atribuiu função lúdica à peça musical e apontou, de modo generalizado, emoção ensejada pela peça musical e, em outras, indicou-a corretamente. Ao mesmo tempo, foi capaz de associar, acertadamente, ritmo a emoção e também de relacionar a peça musical com alguma vivência sua anterior. Na segunda sessão, ocorreram apenas dois tipos de ação, uma do primeiro e outra do terceiro campo da atividade musical, a saber: ele associou movimentos corporais ao tipo de emoção ensejada pela peça musical e apontou corretamente a emoção ensejada por ela ("eu senti monstruidade"). Na quarta e na quinta sessões, também ocorreram pouquíssimas ações: ele identificou, de modo incipiente, elementos da composição musical, indicou, corretamente, a emoção ensejada pela peça, relacionando-a, com acerto, ao timbre. Todavia, na última sessão, ocorreu apenas um tipo de ação em que cometeu erro ao identificar emoção ensejada pela peça musical. $\mathrm{O}$ padrão de ação de Joaquim, nas quatro sessões, não permite uma interpretação do processo de desenvolvimento de sua reação estética.

Finalmente, Raquel, na primeira sessão, apresentou ações no primeiro e terceiro campo, de modo equilibrado. Na segunda sessão, contudo, as ações do campo da atividade pré-musical começaram a predominar, o que se manteve na última sessão. No quarto e no quinto encontro, realizou poucos tipos de ações. Na primeira sessão, ela apontou aspectos fenotípicos da atividade musical, cometeu erros na identificação de instrumentos presentes na execução musical, apontou, de modo generalizado, emoção ensejada pela peça musical, atribuiu função lúdica à atividade musical e associou, incorretamente, ritmo a emoção. Ao mesmo tempo, acertou na identificação de alguns instrumentos e relacionou, corretamente, timbre com determinada emoção. Em certa ocasião, identificou com acerto a emoção ensejada pela peça musical e identificou intenção estética do compositor. Todavia, na segunda sessão, apresentou apenas um tipo de ação do terceiro campo - identificou, acertadamente, o andamento da peça. As demais ações foram, em sua maioria, do primeiro campo (apenas uma do campo da atividade musical ingênua): ela atribuiu função lúdica à atividade musical, apontou detalhes da execução musical de modo descontextualizado, fazendo simulacro de ação de outrem, ante- riormente observada, indicou, erroneamente, a presença de instrumentos musicais na peça, associou movimentos corporais ao tipo de emoção ensejada pela música e errou na identificação da emoção ensejada pela peça musical. Na quarta sessão, realizou um tipo de ação de cada campo e, na quinta, predominaram as ações do campo da atividade pré-musical (imitou, com gestos, o modo de tocar um instrumento, continuou a atribuir função lúdica à atividade musical e errou na identificação da emoção ensejada pela peça). Nessa sessão, realizou apenas um tipo de ação dos outros dois campos, a saber: relacionou peça musical com vivência anterior (segundo campo) e identificou corretamente a emoção ensejada pela música (terceiro campo). Essa variação instável dos tipos de ação de Raquel, ao longo das quatro sessões, impede uma interpretação precisa do processo de desenvolvimento de sua reação estética.

Embora tenha sido constatada, em algumas crianças, uma progressão das ações para níveis mais avançados, ao longo das cinco sessões, o que permite afirmar que, para elas, as sessões de audição com diálogo, efetivamente, contribuíram para o desenvolvimento de sua reação estética, é possível supor que essa progressão tenha sido fruto do tipo de peça musical apresentada. Ou seja, é possível supor que algumas músicas ensejam níveis mais avançados de ação por parte das crianças e a ordem de sua apresentação mascarou esse efeito, passando-se a impressão de um avanço no desenvolvimento. Para verificar essa possibilidade, foram examinados os tipos de ação ensejados, considerando-se as crianças como um todo.

De fato, constatou-se que algumas peças musicais ensejaram mais ações do campo da atividade de análise musical. Foram elas: $1 \times 0$, com a emoção alegria; Rocky Mountains, com a raiva e o canto gregoriano com a calma. Isso poderia conduzir à conclusão de que é a peça em si que enseja essas ações mais avançadas e não o procedimento contínuo de audição dialogada. Todavia, verificando as ações do primeiro campo, constata-se, claramente, um decréscimo na sua ocorrência, com o decorrer das sessões. Isso significa, sem dúvida, que as sessões de audição com diálogo, efetivamente, influem no desenvolvimento da reação estética de algumas crianças. A ocorrência de muitos tipos de ações do terceiro campo, já na segunda sessão, reflete muito mais o fato de algumas dessas crianças já se encontrarem num nível mais adiantado de desenvolvimento da reação estética, isto é, no campo da atividade da análise musical. Ao mesmo tempo, o tipo de música parece ter certo efeito nas ações das crianças. A música $1 \times 0$ (alegria) é a que suscitou mais tipos de ação, seguida de Rocky Mountains (medo) e o canto gregoriano (calma). É possível que isso esteja relacionado ao fato de essas emoções serem mais facilmente reconhecíveis pelas crianças por serem mais conspícuas no seu ambiente social de desenvolvimento. Todavia, isso é algo a ser ainda investigado. 


\section{Discussão e conclusões}

Admitindo-se os postulados básicos da psicologia da arte elaborados por Vigotski, procurou-se, no presente trabalho, realizar um estudo exploratório acerca da emergência da reação estética da criança na atividade musical. Pretendeu-se identificar as emoções vividas por crianças de diferentes idades, na situação de ouvinte de uma obra musical.

Sabe-se que música e fala têm, historicamente, a mesma origem. Em algum momento da nossa história, separaram-se e emergiram, assim, duas atividades distintas que, todavia, ainda guardam relação entre si (ver, a esse respeito, PEDERIVA; TUNES, 2013). Essa origem comum permitiu preservar, na música, algumas propriedades estruturais similares às da fala. Pode-se dizer, concordando com Carrasco (2003), que a música exista para dizer o que a palavra não diz e que a palavra exista para dizer o que a música não diz, mas o que é difícil é dizer o que a música diz. De certo modo, para ele, parece haver uma complementaridade entre música e a linguagem verbal, do mesmo modo que a música complementa-se com o movimento, a ação representada, a dança e as imagens. Mas, ainda que tenham a mesma origem e guardem relação entre si, elas diferem uma da outra, especialmente, no campo da significação. Ele aponta que, distintamente da linguagem, a significação na música não é conceitual, nem objetiva, a não ser no que diz respeito à sua estrutura. Embora esboce uma discussão a respeito dessa questão - por exemplo, o entendimento de que a significação musical ocorre por associação - o autor não apresenta uma solução para o problema. Ou seja, um dos grandes desafios para o estudo do desenvolvimento da reação estética na criança é, exatamente, propor e definir a unidade de análise que corresponderia ao significado, na fala, tal como propõe Vigotski (2001). Por isso, por ter um caráter exploratório, preferiu-se focalizar, no presente estudo, a própria vivência (perejivanie, no russo - ver PRESTES, 2012) das crianças, entendendo-se por esse conceito:

Perejivanie para a criança é exatamente uma unidade simples, relativa à qual não se pode dizer que represente uma influência do ambiente sobre a criança ou uma especificidade da criança; perejivanie é exatamente a unidade da personalidade e do ambiente, assim como está representada no desenvolvimento. Por isso, no desenvolvimento, a unidade dos aspectos da personalidade realiza-se numa série de perejivanie da criança. Perejivanie deve ser entendida como uma relação interna da criança como pessoa com um ou outro aspecto da realidade (VIGOTSKI, 2004, p. 188).

Em seu trabalho denominado $A$ crise dos sete anos, Vigotski (2004) afirma que a percepção das vivências por crianças de distintas faixas etárias é diferente. O bebê, por exemplo, não sabe de suas próprias vivências, não tem consciência delas. Mas, numa criança de sete anos, surge a estrutura de vivências quando ela:

[...] começa a entender o que significa "estou feliz", "estou triste", "estou zangada", ou seja, surge uma orientação consciente em suas próprias vivências. Assim como a criança de três anos descobre suas relações com as pessoas, da mesma forma uma criança de sete anos descobre o próprio fato de suas vivências (PRESTES; TUNES, 2012, p. 333).

As crianças que participaram do presente estudo, todas com sete anos de idade ou mais, já apresentavam condições de falar de suas próprias vivências. É claro que esse falar, nas atividades musicais propostas, não é o falar de música pela própria terminologia musical. Trata-se de um modo corriqueiro de falar sobre música: sem rigor e com base apenas na experiência de audição musical e, é claro, deixando de lado muito da música (CARRASCO, 2003). Entretanto, talvez, resida aí, nesse exato momento em que a criança descobre o fato de suas próprias vivências, a ocasião ideal para investigar o início do desenvolvimento de sua reação estética.

De fato, foi isso o que se constatou. Foi possível identificar, nas crianças, indícios do que foi chamado de campo da atividade pré-musical. Aqui, a característica principal das ações da criança é tratar a peça musical como um todo homogêneo, associando-a a movimentos corporais difusos, atribuindo-lhe funções externas e ainda sem conseguir estabelecer, de algum modo, uma relação de suas propriedades com alguma vivência estético-emocional. Um segundo campo, o da atividade musical ingênua, parece conter as ações da criança que evidenciam uma transição para o terceiro campo, cujas ações já são indício de um modo de analisar a peça musical, ainda que não correspondam, estritamente, ao ponto de vista da terminologia musical técnica.

A audição com diálogo mostrou-se uma atividade musical adequada para a investigação da formação da reação estética da criança, o que traz algumas implicações para a educação musical.

Ainda que pesquisadores e educadores musicais muito se esforcem em busca de compreender modos eficientes para o processo educativo nesse campo, o mito do dom inato permanece, gerando, para os que não o possuem, um aprendizado psicologicamente fadado ao fracasso (PEDERIVA; TUNES, 2013). Assim, a expressão musical por meio de instrumentos é considerada como domínio de raros "talentos" - visão que se faz presente na sociedade, de um modo geral, e, principalmente, no contexto das escolas de músicas especializadas e nos conservatórios - e o músico, o resultado de uma genialidade individualizada. Por sua vez, aqueles que não se adaptam ao padrão de aprendizagem estabelecido pela escola de música formal, ou seja, o padrão de corpos previamente aptos para a atividade, tônus muscular apropriado, audição capaz de reconhecer e identificar frequências, resposta física rápida para a execução de ritmos, reconhecimento e reprodução de tempos e dinâmicas, entre outros, são excluídos do processo ensino-aprendizagem. São entendidos como uma espécie de seres amusicais, ou seja, pessoas que não possuem capacidade e habilidade inatas para serem músicos. A crença no talento ou no dom inato acaba por implicar, dessa forma, um distanciamento entre seres humanos e a música. Gera descrença nas possibilidades humanas e, assim, a exclusão. E, de fato, no âmbito do ensino formal 
da música, a exclusão é um acontecimento, ainda que veladamente praticado e discursivamente negado entre professores (PEDERIVA; TUNES, 2013).

A base biológica da atividade de caráter musical permite afirmar a universalidade da musicalidade. Isto é, se depender das nossas possibilidades como animais humanos, todos somos capazes de nos expressar musicalmente, de expressar nossas emoções por meio de sons, do mesmo modo como, de modo geral, se depender da anatomia e da fisiologia humana, todos somos capazes de nos expressar por meio da fala. Isso é dado ao ser humano, independentemente das formas que possa assumir. A musicalidade possui, assim, caráter universal. Não se trata de um dom para alguns. É um dom para todos.

A atividade musical é uma forma de expressão da experiência humana. Como tal, "os estilos musicais estão baseados no que as pessoas decidiram selecionar da natureza como uma parte de sua expressão cultural e não no que a natureza impôs a elas" (BLACKING, 1995, p. 33), não podendo por isso ser tomada como uma linguagem imediatamente compreensível da qual se espera a produção de respostas específicas. Portanto, o poder expressivo da música articula-se à sua função social. Consequentemente, o seu valor como forma de comunicação da experiência social humana não pode ser auferido apenas pela sua estrutura, mas, essencialmente, pelos modos de sua inserção em uma situação social.

\section{Referências}

BLACKING, J. Music, Culture and Experience: selected papers of John Blacking. Chicago: The University of Chicago Press, 1995.

CARRASCO, N. Sygkronos: a formação da poética musical do cinema. São Paulo: Via Lettera/FAPESP, 2003.

ELLIOT, D. Musical understanding, musical works and emotional expression: implication for education. In: LINES, D. (Ed.). Music education for the new millennium. Oxford: Blackwell, 2005. p. 91-102.

GREEN, L. Musical meaning and social reproduction: a case for retriaving autonomy. In: LINES, D. (Ed.). Music education for the new millennium. Oxford: Blackwell, 2005. p. 75-90.

HEGEL, F. Cursos de estética. São Paulo: EdUSP, 2002. v. 3.

MEYER, L. Emotion and meaning in music. Chicago: Chicago Press, 1984.

PEDERIVA, P. L. M.; TUNES, E. Da atividade musical e sua expressão psicológica. Curitiba: Appris/Prisma, 2013.

PRESTES, Z. R. Quando não é quase a mesma coisa: traduções de Lev Semionovitch Vigotski no Brasil. Campinas: Autores Associados, 2012. Disponível em: <http://www.scielo.br/ pdf/er/n56/0101-4358-er-56-00279.pdf>. Acesso em: 16 dez. 2016.

PRESTES, Z. R.; TUNES, E. A trajetória de obras de Vigotski: um longo percurso até os originais. Revista Estudos de Psicologia, Campinas, v. 29, n. 3, p. 327-340, jul./set. 2012. Cross ${ }^{\text {Ref. }}$

VIGOTSKI, L. S. Psicologia da arte. Tradução de Paulo Bezerra. São Paulo: Martins Fontes, 2001.
VIGOTSKI, L. S. Psirrologuia razvitia rebionka. Tradução livre de Zoia Ribeiro Prestes. Moskva: Eksmo, 2004.

Recebido em: 16 de abril de 2015 Aceito em: 1 de setembro de 2017 